\title{
EVALUASI PENGARUH KOMPETENSI DAN BEBAN KERJA TERHADAP KINERJA PEGAWAI PADA DINAS PENDIDIKAN KABUPATEN TANGGAMUS
}

\author{
Senen Mustakim, Iskandar Hipni, Epi Parela \\ Universitas Sang Bumi Ruwa Juraii \\ senen@saburai.ac.id, iskandarh@saburai.ac.id,epi_parela@gmail.com
}

\begin{abstract}
Abstrak. Tujuan penelitian ini adalah untuk mengetahui pengaruh kompetensi dan beban kerja terhadap kinerja pegawai. Hipotesis pada penelitian ini adalah ada pengaruh kompetensi dan beban kerja baik secara parsial maupun secara simultan terhadap kinerja pegawai. Sampel yang digunakan pada penelitian ini berjumlah 48 pegawai. Teknik pengumpulan data meliputi kegiatan observasi, dokumentasi dan angket. Metode analisis data menggunakan pendekatan kuantitatif dengan bantuan alat statistik SPSS versi 21.0 untuk perhitungan model regresi linier. Hasil pengujian hipotesis pengaruh kompetensi terhadap kinerja secara parsial menunjukkan bahwa kompetensi berpengaruh positif terhadap kinerja dengan kontribusi sebesar $69,9 \%$. Beban kerja berpengaruh positif terhadap kinerja dengan kontribusi sebesar 57,1\%. Pengujian hipotesis secara simultan menunjukkan kompetensi dan beban kerja secara bersama-sama berpengaruh secara positif terhadap kinerja dengan kontribusi sebesar 76,7\%, sedangkan sisanya sebesar 23,3\% merupakan variasi variabel lain yang tidak diteliti.
\end{abstract}

Kata kunci: beban kerja, kinerja pegawai, kompetensi

\section{EVALUATION OF THE EFFECT OF COMPETENCE AND WORKLOAD ON EMPLOYEE PERFORMANCE AT THE EDUCATION OFFICE OF TANGGAMUS DISTRICT}

\author{
Senen Mustakim, Iskandar Hipni, Epi Parela \\ Sang Bumi Ruwa Jurai Universityi \\ senen@saburai.ac.id, iskandarh@saburai.ac.id,epi_parela@gmail.com
}

\begin{abstract}
The purpose of this study was to determine the effect of competence and workload on employee performance. The hypothesis in this study is that there is an effect of competence and workload either partially or simultaneously on employee performance. The sample used in this study amounted to 48 employees. Data collection techniques include observation, documentation and questionnaires. The data analysis method used a quantitative approach with the help of SPSS statistical tool version 21.0 for the calculation of the linear regression model. The results of testing the hypothesis of the influence of competence on performance partially show that competence has a positive effect on performance with a contribution of $69.9 \%$. Workload has a positive effect on performance with a contribution of $57.1 \%$. Simultaneous hypothesis testing shows that competence and workload together have a positive effect on performance with a contribution of $76.7 \%$, while the remaining $23.3 \%$ is a variation of other variables not examined.
\end{abstract}

Keywords: workload, employee performance, competence 


\section{PENDAHULUAN}

Pesatnya laju perkembangan teknologi dewasa ini menuntut organisasi untuk lebih dinamis, oleh karena itu organisasi memerlukan sumber daya manusia yang memiliki nilai yang kuat, fleksibel dan dapat beradaptasi dengan perubahan lingkungan, yaitu sumber daya manusia yang mampu mengimbangi dinamika tersebut. Sumber daya manusia harus memiliki kapasitas yang dibangun di atas pondasi yang kuat, yang sesuai dengan tuntutan perkembangan zaman (Maskur et al., 2020; Sakban et al., 2019; Syazali et al., 2021).

Sumber daya manusia yang berbasis kompetensi dapat meningkatkan kapasitas dan membangun pondasi karena apabila orang-orang yang bekerja dalam organisasi memiliki kompetensi yang tepat sesuai dengan tuntutan pekerjaannya, maka dia akan mampu baik dari segi pengetahuan, keterampilan maupun mental serta karakter produktifnya. Dengan memiliki nilai (value) yang kuat, mereka akan selalu siap menghadapi perubahan sesuai dengan tuntutan organisasi tanpa menghilangkan jati dirinya. Berdasarkan uraian di atas jelaslah bahwa kompetensi merupakan faktor penting dalam meningkatkan kinerja pegawai pada suatu organisasi.

Beban kerja merupakan faktor lain yang dapat mempengaruhi kinerja pegawai (Tjibrata et al., 2017). Peningkatan beban kerja sangat besar pengaruhnya terhadap kinerja karena dengan beban kerja yang tinggi akan dapat memberikan kontribusi positif bagi produktivitas organisasi secara keseluruhan. Penelitian sebelumnya telah meneliti beban kerja sebagai variabel, pengaruh lingkungan kerja, kepuasan kerja dan beban kerja terhadap kinerja pegawai (Nabawi, 2019), Beban kerja merupakan faktor lain yang dapat mempengaruhi kinerja pegawai (Tjibrata et al., 2017).
Peningkatan beban kerja sangat besar pengaruhnya terhadap kinerja karena dengan beban kerja yang tinggi akan dapat memberikan kontribusi positif bagi produktivitas organisasi secara keseluruhan. Penelitian sebelumnya telah meneliti beban kerja sebagai variabel, pengaruh lingkungan kerja, kepuasan kerja dan beban kerja terhadap kinerja pegawai (Nabawi, 2019), pengaruh beban kerja, lingkungan kerja, dan stres kerja terhadap kinerja pegawai PT.FIF Group (Ahmad et al., 2019). Namun demikian, upaya peningkatan beban kerja pegawai bukanlah merupakan hal yang mudah, oleh karena itu pemimpin dituntut untuk mampu terlibat secara langsung dengan bawahannya. Pemimpin harus terus berupaya mendorong peningkatan pemenuhan beban kerja dan mengetahui berbagai indikasi dari turunnya beban kerja para bawahannya (Rohmatulloh \& Satrio, 2017). Keterbaruan dari penelitian ini adalah melihat pengaruh kondisi mengenai beban kerja yang ada di Dinas Pendidikan Kabupaten Tanggamus adalah belum terpenuhi secara maksimal, secara faktual pemanfaatan durasi jam kerja masih belum dapat dikonfirmasi apakah benarbenar diakomodasikan sepenuhnya bagi pelaksanaan tugas dan pekerjaan di kantor oleh semua pegawai.

\section{TINJAUAN TEORITIS}

\section{Kompetensi}

Kompetensi merupakan faktor mendasar yang dimiliki seseorang yang mempunyai kemampuan lebih, yang membuatnya berbeda dengan seseorang yang mempunyai kemampuan rata-rata atau biasa saja (Raharjo et al., 2016). Memiliki sumber daya manusia yang kompeten adalah keharusan bagi perusahaan. Mengelola sumber daya manusia berdasarkan kompetensi diyakini bisa lebih menjamin keberhasilan mencapai tujuan 
(Saputra et al., 2019). Sebagian besar perusahaan memakai kompetensi sebagai dasar dalam memilih orang, mengelola kinerja, pelatihan dan pengembangan serta pemberian kompensasi (Suhardi, 2019). Kompetensi dalam manajemen sumber daya manusia memainkan peran kritikal dan esensial karena di satu sisi merupakan Human capital dan Active agent bagi pengembangan suatu organisasi (Aguk Sridaryono, 2019; Rosiadi et al., 2018), di sisi lain merupakan faktor determinan kapabilitas yang merupakan sekumpulan keahlian dan keterampilan dalam mengkoordinasikan dan mengintegrasikan serangkaian sumber daya yang ada dalam suatu sistem organisasi sehingga menghasilkan serangkaian kompetensi yang akan membentuk kompetensi inti (core competency) (Ungerer, 2016).

Kompetensi sebagai kemampuan seseorang untuk menghasilkan pada tingkat yang memuaskan di tempat kerja, termasuk di antaranya kemampuan seseorang untuk mentransfer dan mengaplikasikan keterampilan dan pengetahuan tersebut dalam situasi yang baru dan meningkatkan manfaat yang disepakati. Kelancaran aktivitas sebuah organisasi sedikit banyaknya bergantung pada seberapa banyak jumlah pekerjaan yang harus diselesaikan oleh pegawai atau karyawan pada sebuah organisasi. Pekerjaan memegang peranan terpenting dalam komponen organisasi. Hal ini, disebabkan karena pekerjaan merupakan bukti konkrit dari keberadaan suatu organisasi. Disamping itu pekerjaan juga merupakan alat atau media mewujudkan suatu tujuan organisasi.

\section{Beban Kerja}

Beban kerja adalah sekumpulan atau sejumlah kegiatan yang harus diselesaikan oleh suatu unit organisasi atau pemegang jabatan dalam jangka waktu tertentu (Astuti
\& Lesmana, 2018). Dalam sebuah perusahaan, pemberian beban bertujuan untuk mengetahui sejauh mana karyawannya dapat diberikan beban kerja yang maksimal dan sejauh mana pengaruhnya terhadap kinerja perusahaan itu sendiri (Tjibrata et al., 2017).

Dengan perkembangan zaman yang semakin maju, karyawan harus bisa menyesuaikan diri dalam segala kondisi. Beban kerja yang semakin berat, banyaknya kebutuhan yang ingin dipenuhi (Rolos et al., 2018). Beban kerja yang terlalu berlebihan akan mengakibatkan dampak yang tidak baik bagi pegawai pada umumnya, yaitu akan menimbulkan kelelahan baik secara fisik maupun mental serta akan menimbulkan reaksi-reaksi emosional seperti sakit kepala, gangguan pencernaan, dan mudah marah. Sedangkan beban kerja yang terlalu sedikit juga akan terjadi pengurangan gerak yang akan menimbulkan kebosanan. Rasa bosan dalam kerja yang dilakukan atau pekerjaan yang terlalu sedikit mengakibatkan kurangnya perhatian pada pekerjaan sehingga secara potensial membahayakan pegawai (Andayani \& Tirtayasa, 2019).

\section{Kinerja Pegawai}

Pekerjaan merupakan sekelompok tugas yang harus dijalankan agar organisasi dapat mencapai tujuannya (Fatmah, 2017). Komponen organisasi yang paling penting adalah pekerjaan atau jabatan. Untuk mencapai tujuan, organisasi perlu menentukan jenis-jenis pekerjaan yang harus dilaksanakan. Pihak manajemen dan khususnya manajemen sumber daya manusia mutlak perlu mempunyai keterangan-keterangan yang lengkap dan tepat mengenai semua jabatan untuk dapat melaksanakan tiap fungsi operatif dengan baik. Mengacu pada teori tersebut maka suksesnya pegawai tergantung pada keberhasilan kinerja unit-unit kerja 
organisasi yang berada di dalamnya dimana terdapat suatu proses manajemen (Ardiansyah \& Sulistiyowati, 2018; Sari \& Hadijah, 2016). Kinerja pegawai merupakan hasil kerja yang dicapai seseorang dalam melaksanakan tugas-tugas yang diberikan kepadanya untuk mencapai target kerja. Pegawai dapat bekerja dengan baik bila memiliki kinerja yang tinggi sehingga dapat menghasilkan kerja yang baik (Andayani \& Tirtayasa, 2019). Dengan demikian, tujuan organisasi dapat dicapai jika tujuan unit-unit organisasinya tercapai secara optimal (Pramudyo, 2013).

Kinerja mempunyai program yang ruang lingkupnya lebih besar dan bersifat menyeluruh kesemua bagian dari organisasi. Elernen-elemen kinerja meliputi teknologi (peralatan, metode kerja) yang digunakan, kualitas dan input termasuk material), kualitas lingkungan fisik (keselamatan, kesehatan kerja. tempat kerja dan keberhasilan), iklim dan budaya organisasi (termasuk supervisi dan kepemimpinan) serta sistem kompensasi dan imbalan.

\section{METODE PENELITIAN}

Objek penelitian ini adalah pegawai di lingkungan Dinas Pendidikan Kabupten Tanggamus yang berjumlah 92 orang pegawai, terdiri dari 45 orang ASN dan 47 non ASN. Analisis Kuantitatif yang dilakukan berdasarkan data primer yang diperoleh dari penyebaran instrument (kuisioner Z) kepada sampel. Teknik penentuan sampel yang digunakan dalam penelitian ini adalah dengan menggunakan rumus Slovin dengan batas toleransi kesalahan $10 \%$ yang diformulasikan kepada seluruh pegawai di Dinas Pendidikan Kabupaten Tanggamus yang berjumlah 92 orang, Dalam Penelitian ini jenis data yang diperlukan adalah data primer.

Sebelum kuesioner digunakan perlu dilakukan uji validitas dan uji reliabilitas.
Pengajuan hipotesis dilakukan dengan melakukan pengujian uji t. Uji t digunakan menguji signifikasi secara parsial (sendirisendiri) pengaruh variabel bebas $\left(\mathrm{X}_{1}\right.$ dan $\mathrm{X}_{2}$ ) terhadap variabel terikat $(\mathrm{Y})$, yaitu dengan cara membandingkan besarnya nilai $t_{\text {hitung }}$ dengan $t_{\text {tabel }}$ jika besarnya nilai $t_{\text {hitung }}$ lebih besar daripada nilai $t_{\text {tabel }}$ berarti variabel bebas berpengaruh secara nyata terhadap variabel terikat., uji f Untuk mengetahui apakah variabel bebas secara bersama-sama memiliki pengaruh terhadap variabel terikat digunakan $\mathrm{Uji} F$, uji koefisien determinasi $\left(\mathrm{R}^{2}\right) \quad \mathrm{Uji} \quad \mathrm{R}^{2}$ dimaksudkan untuk mengukur kemampuan seberapa besar persentase variasi variabel bebas (independen) pada model regresi linier berganda dalam menjelaskan variasi variabel terikat (dependen).

\section{HASIL DAN PEMBAHASAN}

\section{Pengaruh Kompetensi secara parsial terhadap Kinerja Pegawai}

Pengujian pengaruh kompetensi secara parsial terhadap kinerja pegawai, penulis menggunakan uji statistik t (uji t). Apabila nilai $t_{\text {hitung }}>t_{\text {tabel }}$ maka Ho ditolak dan Ha diterima. Sebaliknya apabila nilai $t_{\text {htung }}<$ nilai $t_{\text {tabel }}$ maka Ho diterima dan Ha ditolak. Hasil pengujian hipotesis secara parsial tertera pada gambar 1 di bawah ini:

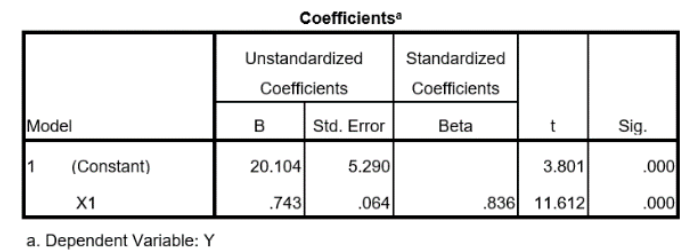

Gambar 1. Pengujian Hipotesis Parsial Pengaruh Kompetensi terhadap Kinerja Pegawai

Dari gambar di atas, di dapat bahwa $t_{\text {hitung }}>t_{\text {tabel }}$ maka Ha diterima. Jika dilihat dari nilai konstanta yang didapat, maka kompetensi berpengaruh positif terhadap kinerja pegawai Dinas Pendidikan 
Kabupaten Tanggamus. Hasil koefisien arah regresi antara kompetensi terhadap kinerja sebesar 0.743 dengan konstanta sebesar 20.104. Dengan demikian, persamaan regeresinya adalah $\mathrm{Y}=20.104+$ $0.743 \mathrm{X}_{1}$. Ini berarti apabila skor kompetensi naik satu skor maka skor kinerja pegawai juga naik sebesar 0,743 .

Untuk mengetahui seberapa jauh variabel kompetensi menjelaskan variabel kinerja dapat dilihat dari nilai koefisien determinasi ( $R$ Square) tertera pada gambar 2 .

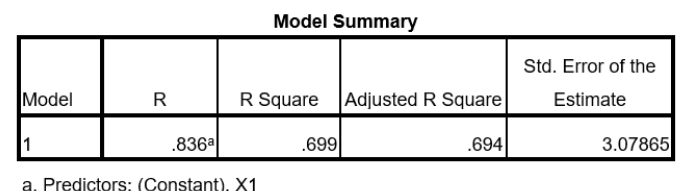

Gambar 2. Hasil Uji Koefisien Determinasi variabel Kompetensi terhadap variabael kinerja pegawai

Dari gambar di atas didapat bahwa Nilai $R$ square sebesar 0.699 artinya sebesar $69,9 \%$ variasi perubahan kinerja mampu dijelaskan oleh variabel kompetensi sedangkan sisanya $30,1 \%$ lagi dijelaskan oleh variabel lain diluar dari variabel penelitian ini.

\section{Pengaruh Beban kerja secara Parsial terhadap Kinerja Pegawai}

Hasil pengujian hipotesis secara parsial pengaruh beban kerja terhadap kinerja tertera pada gambar 3.

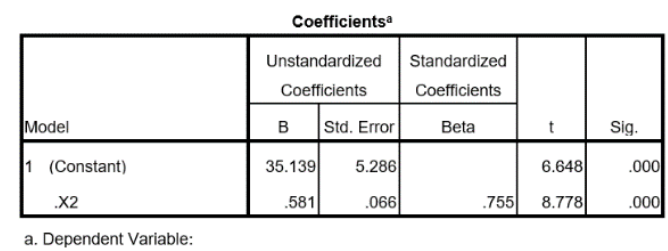

Gambar 3. Pengujian Hipotesis Parsial Pengaruh Beban Kerja terhadap Kinerja Pegawai

Dari gambar di atas, di dapat bahwa $t_{\text {hitung }}>t_{\text {tabel }}$ maka Ha diterima. Jika dilihat dari nilai konstanta yang didapat, maka beban kerja berpengaruh positif terhadap kinerja pegawai Dinas Pendidikan Kabupaten Tanggamus. Berdasarkan gambar di atas diperoleh pula hasil koefisien arah regresi antara beban kerja terhadap kinerja pegawai sebesar 0.581 dengan konstanta sebesar 35.139, dengan demikian, persamaan regeresinya adalah $\mathrm{Y}$ $=35.139+0.581 \mathrm{X}_{2}$. hal ini dapat dijelaskan bahwa apabila skor beban kerja naik satu skor maka skor kinerja pegawai juga naik sebesar 0,581. Besaran kontribusi variabel beban kerja terhadap kinerja dapat dilihat dari nilai koefisien determinasi tertera pada gambar 4.

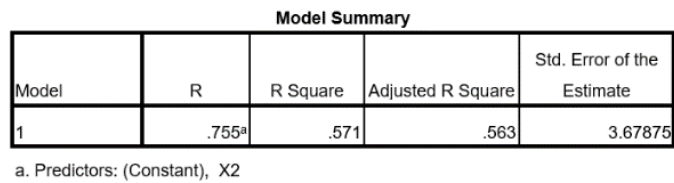

Gambar 4. Hasil Uji Koefisien Determinasi variabel Beban Kerja terhadap variabael kinerja pegawai

Dari gambar di atas diketahui bahwa kontribusi beban kerja terhadap kinerja pegawai Dinas Pendidikan Kabupaten Tanggamus sebesar 0.571 artinya sebesar $57,1 \%$ variasi perubahan variabel kinerja mampu dijelaskan oleh variabel beban kerja sedangkan sisanya $42,9 \%$ lagi dijelaskan faktor-faktor lain yang tidak diteliti dalam penelitian ini.

\section{Pengaruh Kompetensi dan Beban Kerja Secara Simultan terhadap Kinerja Pegawai}

Pengujian pengaruh kompetensi dan beban kerja secara secara simultan terhadap kinerja pegawai Dinas Pendidikan Kabupaten Tanggamus, penulis menggunakan uji $\mathrm{F}$, dengan ketentuan apabila nilai $\mathrm{F}$ hitung $>\mathrm{F}$ tabel maka Ho ditolak dan Ha diterima. Sebaliknya apabila nilai $\mathrm{F}_{\text {htung }}<$ nilai $\mathrm{F}_{\text {tabel }}$ maka Ho diterima dan Ha ditolak. Hasil uji tertera pada gambar 5 . 


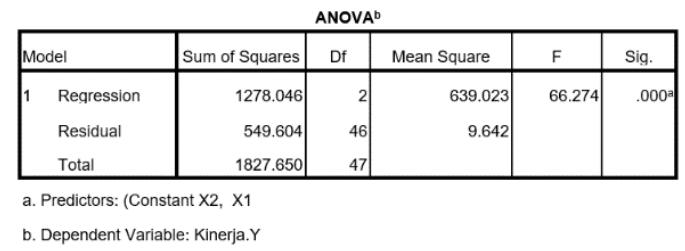

Gambar 5. Pengujian Hipotesis secara Simultan Pengaruh Kompetensi dan Beban Kerja terhadap Kinerja Pegawai

Dari gambar di atas didapat bahwa $\mathrm{F}_{\text {hitung }}>\mathrm{F}_{\text {tabel }}$, maka variabel kompetensi dan variabel beban kerja berpengaruh positif secara bersama - sama (simultan) terhadap kinerja pegawai Dinas Pendidikan Kabupaten Tanggamus .

Pengaruh variabel kompetensi dan beban kerja menjelaskan variabel kinerja dapat dilihat dari nilai kontribusi $(R$ Square) tertera pada gambar 6.

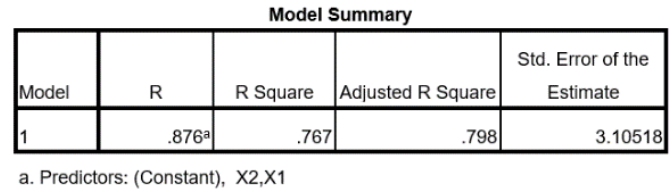

Gambar 6. Hasil Uji Koefisin Determinasi variable Kompetensi dan Beban Kerja terhadap variabael kinerja pegawai

Dari tabel di atas diketahui bahwa nilai $R$ square sebesar 0.767 artinya sebesar $76,7 \%$ variasi perubahan variabel kinerja mampu dijelaskan oleh variabel kompetensi dan beban kerja, sedangkan sisanya 23,3\% lagi dijelaskan faktor-faktor lain yang tidak diteliti dalam penelitian ini.

\section{KESIMPULAN DAN SARAN}

Berdasarkan hasil penelitian diperoleh kesimpulan sebagai berikut: 1) Kompetensi berpengaruh positif terhadap kinerja pegawai Dinas Pendidikan Kabupaten Tanggamus; 2) Variabel Beban kerja berpengaruh terhadap positif kinerja pegawai Dinas Pendidikan Kabupaten Tanggamus; dan 3) Variabel kompetensi dan variabel beban kerja berpengaruh positif secara bersama - sama (simultan) terhadap kinerja.

Berdasarkan hasil penelitian ini, maka saran untuk penelitian lanjutan adalah sebagai berikut: 1) Penelitian di masa yang akan datang hendaknya menjadikan latar belakang pendidikan pegawai menjadi faktor utama dalam menentukan peran dan fungsinya di dalam instansi; 2) Pegawai hendaknya memiliki jiwa profesional dalam bekerja, untuk itu unsur pimpinan sepatutnya memacu bawahan untuk lebih menunjukkan performa kerja yang tinggi, bersikap cepat tanggap dan memiliki inisiatif serta inovasi dalam mengatasi segala tantangan pekerjaan; dan 3) Perlu diterapkan sistem reward and punishment, yaitu memberikan penghargaan kepada pegawai yang mampu menunjukkan hasil kerja yang melebihi target, dan sebaliknya memberikan sanksi kepada pegawai yang tidak mampu mencapai target sasaran yang telah ditetapkan.

\section{DAFTAR PUSTAKA}

Aguk Sridaryono. (2019). Pengaruh Kompetensi dan Kompensasi Terhadap Kinerja Pegawai Negeri Sipil Melalui Produktivitas Kerja Sebagai Variabel Intervening di Politeknik Angkatan Darat Malang. Sketsa Bisnis, 6(2), 99-111. https://doi.org/10.35891/jsb.v6i2.170 5

Ahmad, Y., Tewal, B., Taroreh, R. N., Ekonomi, F., Manajemen, J., \& Ratulangi, U. S. (2019). Pengaruh Stres Kerja, Beban Kerja, Dan Lingkungan Kerja Terhadap Kinerja Karyawan Pada Pt. Fif Group Manado. Jurnal EMBA: Jurnal Riset 
Ekonomi, Manajemen, Bisnis Dan Akuntansi, 7(3), 2811-2820. https://doi.org/10.35794/emba.v7i3.2 3747

Andayani, I., \& Tirtayasa, S. (2019). Pengaruh Kepemimpinan, Budaya Organisasi, Dan Motivasi Terhadap Kinerja Pegawai. Maneggio: Jurnal Ilmiah Magister Manajemen, 2(1), 45-54.

https://doi.org/10.30596/maneggio.v2 i1.3367

Ardiansyah, Y., \& Sulistiyowati, L. H. (2018). Pengaruh Kompetensi dan Kecerdasan Emosional Terhadap Kinerja Pegawai. Jurnal Inspirasi Bisnis Dan Manajemen, 2(1), 91. https://doi.org/10.33603/jibm.v2i1.10 64

Astuti, R., \& Lesmana, O. P. A. (2018). Pengaruh Motivasi dan Beban Kerja terhadap Kinerja Perawat pada Rumah Sakit Umum Mitra Medika Medan. Jurnal Ilman, 6(2), 42-50.

Fatmah, D. (2017). Pengaruh Karakteristik Pekerjaan dan Kompetensi Karyawan terhadap Kinerja Karyawan pada CV. Percetakan Fajar Mojokerto. Jurnal Samudra Ekonomi Dan Bisnis, 8(2), 700-709.

https://doi.org/10.33059/jseb.v8i2.428

Maskur, R., Sumarno, Rahmawati, Y., Pradana, K., Syazali, M., Septian, A., \& Palupi, E. K. (2020). The effectiveness of problem based learning and aptitude treatment interaction in improving mathematical creative thinking skills on curriculum 2013. European Journal of Educational Research, 9(1). https://doi.org/10.12973/eujer.9.1.375

Nabawi, R. (2019). Pengaruh Lingkungan Kerja, Kepuasan Kerja dan Beban Kerja Terhadap Kinerja Pegawai. Maneggio: Jurnal Ilmiah Magister Manajemen, 2(2), 170-183. https://doi.org/10.30596/maneggio.v2 i2.3667

Pramudyo, A. (2013). Implementasi Manajemen Kepemimpinan Dalam Pencapaian Tujuan Organisasi. Jurnal Bisnis Manajemen Dan Akuntansi, I(2), 49-61.

Raharjo, S., Paramita, D. P., \& Warso, M. (2016). Pengaruh kemampuan kerja, pengalaman dan pelatihan terhadap produktivitas kerja karyawan dengan kompetensi kerja sebagai variabel intervening. Journal of Management, 2(2), 1-13.

Rohmatulloh, W. dan, \& Satrio, B. (2017). Pengaruh Lingkungan Kerja, Komunikasi Dan Beban Kerja Terhadap Kinerja Karyawan. Jurnal Ilmu Dan Riset Manajemen, 6(9), 2461-0593.

Rolos, J. K. R., Sambul, S. A. P., \& Rumawas, W. (2018). Pengaruh Beban Kerja Terhadap Kinerja Karyawan Pada PT. Asuransi Jiwasraya Cabang Manado Kota. Jurnal Administrasi Bisnis, 6(4), 1927.

https://doi.org/10.35797/jab.6.004.20 18.21074.19-27

Rosiadi, A., Setiawan, M., \& Moko, W. (2018). Praktek Manajemen Sumber Daya Manusia Berbasis Kompetensi pada Organisasi Sektor Publik. Jurnal Manajemen Dan Kewirausahaan, 6(2), 156-169. https://doi.org/10.26905/jmdk.v6i2.22 08

Sakban, S., Nurmal, I., \& Bin Ridwan, R. (2019). Manajemen Sumber Daya Manusia. Journal of Administration and Educational Management (Alignment), 2(1), 93-104. https://doi.org/10.31539/alignment.v2 i1.721

Saputra, K. A. K., Pradnyanitasari, P. D., Priliandani, N. M. I., \& Putra, I. G. B. N. P. (2019). Praktek Akuntabilitas 
Dan Kompetensi Sumber Daya Manusia Untuk Pencegahan Fraud Dalam Pengelolaan Dana Desa. Krisna: Kumpulan Riset Akuntansi, 10(2), 168-176.

Sari, R. N. I., \& Hadijah, H. S. (2016). Peningkatan Kinerja Pegawai Melalui Kepuasan Kerja Dan Disiplin Kerja. Jurnal Pendidikan Manajemen Perkantoran, $\quad 1(1), \quad 204$. https://doi.org/10.17509/jpm.v1i1.338 9

Suhardi, S. (2019). Pengaruh Motivasi Kerja, Kompetensi, Lingkungan Kerja dan Kompensasi Terhadap Kinerja Karyawan PT. Asuransi Jiwa di Kota Batam Dengan Organizational Citizenship Behavior Sebagai Variabel Intervening. Jurnal Benefita, 4(2), 296. https://doi.org/10.22216/jbe.v4i2.367 0

Syazali, M., Iqoh, U., Mufty, V. F., \& Rahmawati, Y. (2021). Auditory intellectually repetition learning model and trade a problem learning model on row and series algebraic material: The influences on numerical skills. IOP Conference Series: Earth and Environmental Science, 1796(1). https://doi.org/10.1088/17426596/1796/1/012104

Tjibrata, F. R., Lumanaw, B., \& Dotulang O.H, L. (2017). Pengaruh Beban Kerja Dan Lingkungan Kerja Terhadap Kinerja Karyawan Pt.Sabar Ganda Manado. Jurnal EMBA, 5 No.2(Juni), 1570-1580.

Ungerer, L. M. (2016). Digital curation as a core competency in current learning and literacy: A higher education perspective. International Review of Research in Open and Distance Learning, 17(5), 25-27. https://doi.org/10.19173/irrodl.v17i5. 2566 